\title{
Subjective Perceptions of Economic Inequality in Argentina
}

\author{
Franco Bastias* \\ Instituto de Investigaciones en Psicología Básica y Aplicada, Universidad Católica de Cuyo \\ Consejo Nacional de Investigaciones Científicas y Técnicas \\ E-mail: francobastias@uccuyo.edu.ar \\ Dayana Amante \\ Instituto de Investigaciones en Psicología Básica y Aplicada, Universidad Católica de Cuyo \\ Pablo Agustín Avendaño \\ Instituto de Investigaciones en Psicología Básica y Aplicada, Universidad Católica de Cuyo \\ Universidad del Norte Santo Tomás de Aquino
}

\begin{abstract}
This publication was sponsored by the Secretaría de Estado de Ciencia, Tecnología e Innovación of the San Juan Government, Argentina.

\section{Abstract}

In Argentina, inequality and poverty have reached alarming levels. However, societies that register high indexes of inequality do not necessarily present strong demands for a fairer society. According to studies in Psychology, social demands are conditioned more often by the perception of inequality than by real inequality. Furthermore, there are important variations in the perception of inequality among different population sectors. The current research intends to identify how variables, such as sex, age, educational level, objective status and subjective status, are associated with variations in the perception of inequality. It is a quantitative correlational study, whose sample consisted of 400 adults from Argentina, aged between 18 and 74 years $(M=38.57, S D=13.072)$. Participants answered a self-administered questionnaire regarding inequality. The results indicate that people perceive lower economic inequality than that registered by national statistics and this underestimation is conditioned by and associated with sociodemographic variables. Perceptual biases are higher when income and educational levels are lower. In addition, women perceive inequality more than men do. However, no variations in the perception of inequality were found according to the age of the respondents. The implications of this research and its contribution to promoting the study of inequality are discussed.
\end{abstract}

Keywords: perceptual biases - economic inequality - sociodemographic variables - subjective status

DOI: $10.7176 / \mathrm{DCS} / 9-5-05$

Publication date:May $31^{\text {st }} 2019$

\section{Introduction}

In this section, firstly the social and economic situation of Argentina is described, with special emphasis placed on national indexes of poverty and inequality. Secondly, research on the study of the perception of inequality is presented and the subject is broadly explained.

In Argentina, poverty and inequality are highly upsetting. Recent studies in Argentina, carried out in the third quarter of 2018 , reveal that $25.6 \%$ of households and $33.6 \%$ of the population (one in three Argentines) live under the poverty line (Observatorio de la Deuda Social Argentina [ODSA], 2018). As regards economic inequality, in 2018 , the earnings gap was 18.1 . That is, workers in the top $10 \%$, whose average monthly income was $\$ 45,425$ (at that time $\$ 1,133$ USD), earned around 18 times more than workers in the bottom $10 \%$, who had an average income of \$2,511 (63 USD) (Instituto Nacional de Estadística y Censos [INDEC], 2018). Note that this earnings gap also considers both formal and informal work and underemployment, and does not specify the type of occupation or profession. Therefore, for the purposes of this work and in a complementary manner, the earnings gap of the registered work is calculated. To do this, we divide the average monthly salary of the managing director of large companies in various areas, as reported by the consulting firm Page Group (2018), by the minimum salary ${ }^{1}$ indicated by the Ministerio de Trabajo, Empleo y Seguridad Social [MTEySS] (2018), both for the third quarter of 2018. This earnings gap is also 18 .

Research has indicated that some societies that register high inequality indexes do not necessarily show a high perception of this inequality (Castillo, Gerlitz et al., 2008; Castillo, Mühleck et al., 2008). For example, a study conducted by Niehues (2014) found that countries such as Germany, France and Switzerland share approximately the same degree of income inequality, but their perceptions regarding income differences differ widely. Also, in Chile, although inequality grew significantly in the first decade of this century, the perception of inequality is almost the same in 1999 as it is in 2009 (Castillo, 2012). This evidence has led some researchers to ask about the existence of perceptual biases toward real inequality, which in turn would encourage or inhibit

\footnotetext{
${ }^{1}$ The minimum salary was around $\$ 10,700$ (267 usd), for workers who work full-time legal work (MTEySS, 2018).
} 
actions towards real inequality (Castillo et al., 2012).

Among the studies on the perception of inequality, those carried out within the framework of the International Social Survey Program [ISSP] stand out. This program conducts opinion surveys on different social issues, including the perception of inequality, and works with representative samples of the populations of each participating country (currently more than 40 countries). The ISSP database has been analyzed by several authors to study the perceived inequality in their societies (Castillo, 2012; Corneo \& Grüner, 2002; Engelhardt \& Wagener, 2014; Niehues, 2014; Rodríguez, 2014). In addition to these efforts, several international studies can be mentioned (Castillo, Perales \& Cousinou, 2011; Evans \& Kelly, 2004, 2018; Festinger, 1957; Gimpelson \& Treisman, 2015; Hirschman, 1973; Irwin, 2016; Wegener, 1987, 1990, 1992; Schalembier, 2015; Stekelenburg, \& Klandermans, 2013), although in this article we will focus on the studies carried out in Latin America.

We highlight the important contributions of Castillo and his team (Castillo, 2009, 2011, 2012; Castillo, Miranda \& Carrasco, 2012), who worked with the ISSP surveys and the Centro de Estudios Públicos in Chile. In their first study (Castillo, 2009), the perceived earnings gap was considered as a measure of perceived inequality. This consists specifically in asking respondents what they believe the salary of a high-status occupation would be, in this case the managing director of a large corporation, and what they believe the salary of a low-status occupation would be, here an unskilled factory worker. Based on these two values, the perceived gap is calculated. The results show that individuals with lower incomes perceived a smaller earnings gap than those with higher incomes. The satisfaction with economic income also has a significant effect, where the higher the satisfaction, the smaller the perceived gap and the smaller the gap considered to be fair.

In a second study, Castillo (2012) compared perceived inequality in Chile between the years 1999 and 2009. The analyzed data correspond to the surveys of the inequality module of the ISSP carried out during those years. The results point out that inequality in Chile tends be underestimated in perceptual terms. Both in the 1999 and 2009 surveys, respondents perceived that a manager would earn a little more than 30 times what an unskilled worker would earn; however, these data contrast with economic indicators that show that this gap would have increased up to 100 times by 2009 .

In a third investigation (Castillo et al., 2012), the influence that objective status (calculated from income and educational level), political position and satisfaction with one's salary have on perceptual variables was determined. Perceptual measures used included the general perception of inequality, the perceived earnings gap and the diagrammatic perception of inequality, although the results indicate that these three perceptual indicators are only weakly associated with each other. However, it is possible to identify variations in the perception of salaries related to status variables, those with a higher income and a higher level of education are likely to perceive greater inequality between salaries. Likewise, an inverse association between the subjective status variable and the diagrammatic perception was observed, suggesting that those who perceive themselves as having a high socioeconomic status tend to perceive society as being less unequal.

On the other hand, research carried out by Rodríguez (2014) in Argentina is also relevant. The author analyzes 2009 ISSP data (ISSP Research Group, 2017) from a sample of 1,130 Argentines. This research presents as dependent variables the three measures of perception of inequality considered by Castillo et al. (2012), and as independent variables, mainly social status (years of education, occupational position and total household income) and subjective position (self-positioning on a 10 point scale). The results regarding the general perception of inequality indicate that $91.9 \%$ "agree" and "strongly agree" with the statement: "Income differences in Argentina are too large". In relation to the analysis of the diagrammatic perception of inequality, the most chosen diagram was the one with the greatest inequality, Type A, at $45.58 \%$. With respect to the perceived earnings gap between the manager and worker occupation, this presented an average of 1.93 ( $S D=$ 0.69 ).

When asked about the salaries of high and low status occupations, male respondents assigned higher incomes to both occupations as compared to female respondents, and it was the female respondents who showed the greatest agreement with the statement that suggests the existence of large salary differences (Rodríguez, 2014). Likewise, it can be observed that as years of education increase, greater inequality in Argentina is perceived, especially by those who had completed 18 years of educational instruction (university level), compared to those who had completed only 7 years of primary-level education. In general terms, people with higher social status are likely to perceive real inequality in the three indicators considered (general perception, perceived earnings gap and diagrammatic perception), as opposed to people of lower social status. Finally, a positive correlation between age and perception of inequality was identified.

With this background, the aim of this study is to identify if there are differences between the real economic inequality in Argentina, informed by public and private organizations, and the inequality actually perceived by Argentine society. Likewise, we ask ourselves how the perception of inequality varies in relation to age, sex, educational level, subjective status and objective status. As the literature review shows, the vast majority of the research carried out on the subject of the perception of inequality has used and analyzed a non-proprietary database, created mainly by international organizations. The present study uses its own data collection, which 
has made it possible to evaluate the functioning of the data collection instrument and to test some innovations. For example, in addition to studying the salary of the manager and the unskilled worker, respondents were offered the possibility of proposing what they would consider to be the worst paid formal job in Argentina. This decision was motivated by the high levels of disagreement found in the pilot questionnaire regarding which job best represented the low status occupation.

\section{Methods}

\subsection{Type of study and sample}

This is a correlational study with a non-probabilistic sample of 400 Argentine adults, aged between 18 and 74 years $(M=38.57, S D=13.072)$. Of the total participants, $56.5 \%(n=226)$ were female and $43.5 \%(n=174)$ male. $83 \%(n=332)$ of the respondents were currently working. With respect to the self-perceived social class, $6.8 \%(n=27)$ considered themselves low class, $30.3 \%(n=121)$ lower middle class, $58.5 \%(n=234)$ middle class, $4 \%(n=16)$ as upper middle class and only 3\% $(n=1)$ upper class. Regarding educational level, $1.3 \%(n=$ 5 ) of the participants had not completed primary education, $2.3 \%(n=9)$ had completed primary education, $9 \%$ $(n=36)$ had not completed secondary education, $26.8 \%(n=107)$ had completed secondary education, $34.3 \%(n$ $=137)$ had completed university level and $26.5 \%(n=106)$ had not completed university level.

The data collection was carried out during the third quarter of 2018, so that the salary mentioned by the respondents referred to August or September earnings. The third quarter of the year was strategically chosen since it is when two entities, one private -ODSA- and one public -INDEC-, coincide in the data collection with their national survey, which allowed us to know the real inequality in the country. In other words, we were able to make comparisons between real and perceived inequality over the same period of time. This is very important to take into account in Argentina's current context with large macroeconomic instability, where, for example, inflation was 47\% in 2018 (INDEC, 2019).

\subsection{Instrument}

Prior to the data collection, a small pilot sample of 18 surveys was carried out to check the instrument. Each participant was briefly interviewed to find out his/her opinion: i) They were asked if any question was difficult to understand; ii) if they wanted to change wording of the questionnaire; iii) if they could give a brief reflection on what the questionnaire was addressing; and, finally, iv) if there was any question for which they felt encouraged to give a certain answer. Firstly, several respondents felt that there were registered or formal jobs that were worse paid than the unskilled factory worker. Secondly, some mentioned that they would not indicated their income level since they felt that they were revealing very private information. Thirdly, with respect to what the questionnaire seeks to address, the responses were varied, including political preferences, inequality and earnings differences. And, finally, no participant said that he had felt encouraged to provide any particular response. The final version of the instrument used in the present study consists of the following series of variables:

2.2.1. Perceived earnings gap.

The perception of the earnings gap is a measure of perception of inequality that relates the extremes of salary distribution through answers provided by respondents about the income that they believe is obtained by highstatus and low-status occupations. Based on ISSP's 2009 survey (ISSP Research Group, 2017) applied in Argentina, the high-status occupation was a managing director of a large company and the low-status occupation was an unskilled factory worker. The questions asked were: What do you think a managing director of a large company earns per month? What do you think an unskilled factory worker earns per month? This allows for the evaluation of the existence of extreme economic situations based on salary within the framework of the same company or work environment. Likewise, the present study allowed respondents to propose a low-status occupation with which to calculate an alternative perceived earnings gap. To calculate both perceived earnings gaps, the salary value of the high-status occupation was divided by that of the low-status occupation. In the case that the respondents answered with earnings per hour, per day or per week, this was multiplied by 160, 21 and 4, respectively, assuming a full-time monthly occupation.

2.2.2. Perceived type of society.

A diagrammatic representation of inequality is proposed with five categories so that the respondent chooses which diagram is more similar to the current Argentine society and may also choose what Argentine society should be according to his/her perception. The diagrams are coded taking into account that " 1 " represents less perception of inequality, this would be choosing Type E to refer to Argentina, and "5" represents greater perception of inequality, this would be choosing Type A to refer to Argentina. 

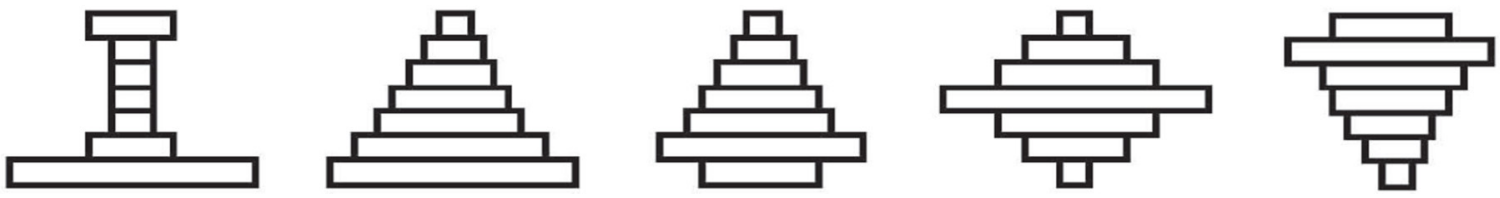

\begin{tabular}{|c|c|c|c|c|}
\hline $\begin{array}{l}\text { Type A } \\
\text { Argentina is a society } \\
\text { with a small elite at the } \\
\text { highest level, very few } \\
\text { people in the middle and } \\
\text { the great mass of people } \\
\text { in the lowest level. }\end{array}$ & $\begin{array}{l}\text { Type B } \\
\text { Argentina is a pyramid } \\
\text { society with a small } \\
\text { elite at the highest level, } \\
\text { more people in the } \\
\text { middle and most people } \\
\text { at the lowest level. }\end{array}$ & $\begin{array}{l}\text { Type C } \\
\text { Argentina is a } \\
\text { pyramid } \\
\text { society except } \\
\text { that only a few } \\
\text { people are at } \\
\text { the bottom. }\end{array}$ & $\begin{array}{l}\text { Type D } \\
\text { Argentina } \\
\text { is a society } \\
\text { with most } \\
\text { people in } \\
\text { the middle. }\end{array}$ & $\begin{array}{l}\text { Type } \mathbf{E} \\
\text { Argentina is a } \\
\text { society with many } \\
\text { people near the } \\
\text { highest level and } \\
\text { only a few near the } \\
\text { lowest level. }\end{array}$ \\
\hline
\end{tabular}

Figure 1. Perceived types of society. Source: 2009 ISSP Survey (ISSP Research Group, 2017).

2.2.3. General perception of inequality.

On a Likert five-point scale whose extremes vary between 1 "totally disagree" and 5 "totally agree", the variable of general perception of inequality is addressed with the following statement: "The differences in income in Argentina are too large".

2.2.4. Education.

Variable that refers to the maximum level of instruction completed by participants. It is divided into six categories from incomplete primary education to complete university education.

2.2.5. Objective status

To discover objective status, questions were included about the number of household members, the total family and individual income of the last month (August and September 2018). Taking into account third quarter data from INDEC (2018) on the deciles of total family and per capita income, participants were placed within a specific decile to establish their objective status.

2.2.6. Subjective status

Determined through the use of: "Mark on this scale, where your household would be located in our country". A scale of 1 (low-income household) to 10 (high-income household) was then offered. In addition, the selfperception of social class is provided through the following values: low class, low average, medium, high and high mean, which allows us to complement the subjective status variable.

2.2.7. Other variables researched

Specific questions were included to research sociodemographic variables such as age and sex.

\section{Results}

One of the innovations presented by this study is the alternative of calculating the perceived earnings gap between occupations of high and low status proposed by respondents. As indicated in Table 1, the five most frequent low status occupations were teacher with $26 \%(\mathrm{f}=87)$, domestic worker $18 \%(\mathrm{f}=58)$, construction worker $13 \%(f=43)$, agricultural worker $9 \%(f=30)$, and finally retail employee $7 \%(f=23)$.

Table 1. Low status occupation proposed by respondents

\begin{tabular}{lllll}
\hline Proposed occupation & $f$ & Percentage & $\begin{array}{l}\text { Monthly } \\
\text { earnings }\end{array}$ & $\begin{array}{l}\text { Earnings in } \\
\text { US dollars }\end{array}$ \\
\hline Teacher & 87 & 26 & $\$ 15627$ & $\$ 384$ \\
Domestic worker & 58 & 18 & $\$ 9256$ & $\$ 227$ \\
Construction worker & 43 & 13 & $\$ 11533$ & $\$ 283$ \\
Agricultural worker & 30 & 9 & $\$ 9623$ & $\$ 236$ \\
Retail employee & 23 & 7 & $\$ 15195$ & $\$ 373$ \\
\hline
\end{tabular}

Note. The first five occupations of a total of 36 are presented.

As shown in Table 2, we analyzed and compared, on the one hand, the average of the perceived earnings gap $(M=7,988, S D=9,563)$ between occupations of high and low status, using manager and factory worker. On the other hand, the perceived earnings gap between manager and the low status occupation proposed by the respondent was also calculated $(M=9,212 S D=7,725)$. The comparison shows that the perceived earnings gap between manager and the proposed occupation is higher. The mean of the earnings for the proposed occupations was $\$ 13,735$ and for an unskilled factory worker was $\$ 16017$.

Table 2. Perceived earnings gaps

\begin{tabular}{llllll}
\hline Variables & Min & Max & $M$ & $S D$ & $M d$ \\
\hline Perceived earnings gap & 0.4 & 125 & 7,988 & 9,563 & 5.1 \\
Perceived earnings gap with proposed occupation & 0.4 & 67 & 9.212 & 7.725 & 7.1 \\
\hline
\end{tabular}


Subsequently, general perception and diagrammatic representation of inequality were analyzed. In the case of the first variable, $75.8 \%(n=303)$ of the participants said they were "partially in agreement" or "totally in agreement" with the statement "Income differences in Argentina are too great". With respect to the second variable, the diagrams c005Ahosen according to the perception of the participants were: first the Type A diagram with $43.1 \%(f=172)$, then the Type B diagram with $38.8 \%(f=155)$, followed by the Type $D$ with $11 \%(f=44)$. The Type $\mathrm{C}$ and $\mathrm{E}$ diagrams both presented $3.5 \%(\mathrm{f}=14)$. On the other hand, it is observed that the diagram referring to how respondents believe that Argentine society should be is Type D with $56 \%$ ( $f=44.3$ ), followed by Type E with $33.3 \%(f=133)$, and Type $\mathrm{C}$ with $14.0 \%(\mathrm{f}=56)$. The lowest percentages correspond to the Type B diagram with $7 \%(\mathrm{f}=28)$ and to Type A with $1.3 \%(\mathrm{f}=5)$.

Table 3. Correlation matrix of study variables

\begin{tabular}{|l|c|c|c|c|c|c|c|c|c|}
\hline & 1 & 2 & 3 & 4 & 5 & 6 & 7 & 8 & 9 \\
\hline 1 Age & --- & & & & & & & & \\
\hline 2 Educational level & $.16^{* *}$ & --- & & & & & & & \\
\hline 3 Objective status & .02 & $.40^{* *}$ & --- & & & & & & \\
\hline 4 Subjective status & $-.11^{*}$ & $.24^{* * *}$ & $.36^{* * *}$ & --- & & & & & \\
\hline 5 Self-perceived social class & $-.13^{* *}$ & $.21^{* * *}$ & $.39^{* * *}$ & $.47^{* * *}$ & --- & & & & \\
\hline 6 Perceived earnings gap & .04 & $.13^{*}$ & $.21^{* * *}$ & .02 & .02 & --- & & & \\
\hline 7 Perceived earnings gap with p.o. & .07 & $.13^{*}$ & $.16^{* *}$ & .06 & .07 & $.66^{* * *}$ & --- & & \\
\hline 8 Diagrammatic perception & .07 & .05 & $.11^{*}$ & $-.11^{*}$ & $-.10^{*}$ & $.12^{*}$ & .02 & --- & \\
\hline 9 General perception of inequality & .07 & .08 & .04 & .07 & $.11^{*}$ & .07 & .07 & $.16^{* *}$ & --- \\
\hline
\end{tabular}

$* . p<0.05 * * . p<0.01 * * * . p<0.001$. Note. p.o.: proposed occupation. Note. Some correlations were calculated using Pearson's $r$ and others with Spearman's rho.

As shown in Table 3, taking into account the three measures of perception, first, it is identified that the general perception of inequality presents a significant positive correlation with the self-perceived social class variables $(\mathrm{r}=.11, \mathrm{p}<0.05)$ and Diagrammatic representation of inequality $(\mathrm{r}=.16, \mathrm{p}<0.01)$. Second, taking into account the measure of the diagrammatic perception of inequality, a positive correlation can be seen with the variables objective status $(\mathrm{r}=.11, \mathrm{p}<0.05)$ and perception of the perceived earnings gap $(\mathrm{r}=.12, \mathrm{p}<0.05)$, and a negative correlation with subjective status $(\mathrm{r}=-.11, \mathrm{p}<0.05)$ and self-perceived social class $(\mathrm{r}=-.10, \mathrm{p}<0.05)$. Third, the perceived earnings gap with the proposed occupation presents an association with objective status ( $\mathrm{r}$ $=.16, \mathrm{p}<0.01)$ and with educational level $(\mathrm{r}=.13, \mathrm{p}<0.05)$. At the same time, the perceived gap between the occupations of manager and worker maintains a positive correlation with educational level $(\mathrm{r}=.13, \mathrm{p}<0.05)$ and a bit higher with objective status $(\mathrm{r}=.21, \mathrm{p}<0.001)$.

Table 4. Variables studied according to sex and PGD

\begin{tabular}{llllll}
\hline & \multicolumn{4}{l}{ Female $(n=22)$} & \multicolumn{3}{l}{ Male $(n=163)$} \\
\hline & $M$ & $S D$ & $M$ & $S D$ & $t$-value \\
General perception of inequality & 4.34 & 1.24 & 3.89 & 1.44 & $3,304^{*}$ \\
\hline
\end{tabular}

$* p<0.001$

With regard to sex, as shown in Table 4, female respondents $(\mathrm{M}=4.34, S D=1.24)$ perceive more inequality than male respondents $(M=3.89, S D=1.44)$. The only measure of perception that showed statistically significant differences was general perception of inequality $(t=3.304$, gl $=383$, bilateral significance $=0.001)$.

\section{Discussion}

The perceived earnings gap between manager of a large company and unskilled factory worker was approximately eight. On the other hand, the perceived earnings gap between the manager and the low-status occupation proposed by the respondents was nine. These findings indicate that the variant introduced by this study to explore the gap allowed for a more pronounced per capita income earnings gap. Both measurements show that the perceived gap is underestimated, since, according to the real earnings gap calculated (see above), the gap is actually at least 18 . These results agree with the literature in which the perceived inequality is far from being a mirror of the reality and societies that register high indexes of inequality do not necessarily show a high perception of it (Castillo, Gerlitz et al., 2008; Castillo, Mühleck et al., 2008; Castillo, 2012; Rodríguez, 2014).

The low status occupation proposed by the participants which obtained the highest percentage is that of teacher with 26.4\%. Nevertheless, according to the MTEySS (2018), the worst paid occupation in Argentina is not that of teacher, but that of workers in the agricultural sector. This perception may have been conditioned by the pressures and demands that have arisen in Argentina recently regarding teachers, an issue which has been quite covered by the media in 2018. Strikes and mobilizations have been in the news with the dispute between the teachers' union and the Government of the Province of Buenos Aires over salary increases in the face of inflation.

Regarding the general perception of inequality, $75.8 \%$ of the participants said they were "partially in 
agreement" or "totally in agreement" with the statement "Income differences in Argentina are too great". These results are close to the $91.9 \%$ obtained by the Rodríguez study (2014), which used data collected in 2009 in Argentina.

As regards the diagrammatic perception of inequality, most participants consider that there is an unequal distribution of wealth in Argentine society (A and B) and, in turn, they would prefer a more egalitarian distribution (D). Therefore, the results obtained in the present investigation agree with those obtained by Jorrat (2011) and Rodríguez (2014) for the Argentine population.

Considering the measure of general perception of inequality, females perceive inequality more than males, coinciding with the results of Castillo et al. (2011) in Chile. However, there is no positive association between age and perception of inequality, which is contrary to the findings of Castillo et al. (2011).

Research indicates that people with higher economic incomes and a high educational level have a greater capacity to distinguish wage inequality from a high status occupation and a low status one (Castillo et al., 2012; Wegener, 1990). Similarly, in the present study, it is observed that the higher the educational level and the better the income, the closer is the perceived earnings gap to the real gap between occupations. According to Rodríguez (2014) and Castillo (2009), the influence of the educational level on the perceived gap may be due to the fact that the more education one has, the greater the access to information on high-status salaries. With respect to subjective status, the results do not seem to be consistent. Correlational analysis shows that the greater the subjective status, the greater the diagrammatic perception of inequality; however, it seems to have a negative relationship with the general perception of inequality. We propose that future studies more precisely address the role that self-positioning can play on a certain social class and socioeconomic level in the perception of inequality.

Finally, among the limitations of this study, we point out that as we have worked with a non-representative intentional sample, the results obtained cannot be generalized to the total population of Argentina. On the other hand, a difficulty was noted among the respondents in the interpretation of one of the items, included in the ISSP 2009 survey (ISSP Research Group, 2017), which measures the perception of the earnings gap: Do you think that you earn more than you deserve, Is it okay, or is it less than what the general manager / unskilled factory worker / worker of the proposed occupation deserves? The mentioned indicator was finally discarded for the present article, because $72 \%$ inconsistencies were identified when comparing the answer to said question and the amount of salary perceived and considered fair for each occupation.

As final considerations, we can mention that in spite of having numerous investigations with objective measurements of inequality in Argentina, this is the only study in this country in the last decade that considers subjective measurements. Furthermore, the present work has its own data collection, unlike other studies that analyze a database generated by international organizations. This allowed for some additional indicators to be added to the instrument, such as the possibility that respondents could propose an occupation, taking into account their own context, to calculate the earnings gap.

We hope this research and its contribution will promote the study of the phenomenon of inequality considering both objective and subjective measurements. In addition, the study of how societies perceive inequality and the variables that can function as filters or perceptual biases is necessary to understand the support of policies against inequality and prosocial actions. Thus, future research could deepen the analysis of the relationship between measures of perception of inequality and social demands for the redistribution of resources.

\section{References}

Castillo, A. M. J., Perales, I. M., \& Cousinou, G. M. (2011). Percepción de la desigualdad y demanda de políticas redistributivas en Andalucía. Colección Actualidad (Centro de Estudios Andaluces), (61), 1-27.

Castillo, J. C. (2009). ¿Cuál Es La Brecha Salarial Justa? Opinión pública y legitimación de la desigualdad económica en Chile. Centro de Estudios Públicos, 238-260.

Castillo, J. C. (2011). Legitimacy of inequality in a highly unequal context: Evidence from the Chilean case. Social Justice Research, 24(4), 314-340.

Castillo, J. C. (2012). Is Inequality becoming just? Changes in public opinion about economic distribution in Chile. Bulletin of Latin American Research, 31(1), 1-18.

Castillo, J. C., Miranda, D., \& Carrasco, D. (2012). Percepción de desigualdad económica en Chile: medición, diferencias y determinantes. Psykhe, 21(1), 99-114.

Castillo, J., Gerlitz, J., \& Schrenker, M. (2008). Perception and legitimacy of income inequality in international comparison. Ponencia presentada en el APSA Annual Conference, Boston, MA, Estados Unidos.

Castillo, J., Mühleck, K., \& Wegener, B. (2008). The empirical approach to the study of social justice: A research agenda for Latin America. México: Regional Bureau for Latin America and the Caribbean of United Nations Development Program (RBLAC-UNDP).

Corneo, G., \& Grüner, H. P. (2002). Individual preferences for political redistribution. Journal of public Economics, 83(1), 83-107. 
Engelhardt, C. \& Wagener, A. (2014). Biased perceptions of income inequality and redistribution. CESifo Working Paper Series.

Evans, M. D., Kelley, J., \& Kolosi, T. (1992). Images of class: Public perceptions in Hungary and Australia. American Sociological Review, 54(4), 461-482.

Evans, M., \& Kelley, J. (2018). Strong welfare states do not intensify public support for income redistribution, but even reduce it among the prosperous: a multilevel analysis of public opinion in 30 countries. Societies, $8(4), 105-157$.

Evans, M.D., \& Kelley, J. (2004). Subjective social location: data from 21 nations. International Journal of Public Opinion Research: 16(1).

Festinger, L. (1957). A Theory of Cognitive Dissonance. Evanston, IL: Row, Peterson. Germani, G. (2010). La sociedad en cuestión. Buenos Aires: Consejo Latinoamericano de Ciencias Sociales.

Gimpelson, V., \& Treisman, D. (2015). Misperceiving inequality. Cambridge, MA: National Bureau of Economic Research. Retrieved from: https://www.nber.org/papers/w21174.pd

Hirschman, A. O., \& Rothschild, M. (1973). The changing tolerance for income inequality in the course of economic development: With a mathematical appendix. The Quarterly Journal of Economics, 87(4), 544566.

Instituto Nacional de Estadística y Censo (2018). Evolución de la distribución del ingreso (EPH). INDEC Tercer trimestre de 2018.

Instituto Nacional de Estadística y Censo (2019). Índice de precios al consumidor (IPC), vol. $3 \mathrm{n}^{\circ} 1$.

Irwin, S. (2016). Lay perceptions of inequality and social structure. Sociology, 52(2), 211-227.

ISSP Research Group (2017). International Social Survey Programme: Social Inequality IV-ISSP 2009. GESIS Data Archive, Cologne. ZA5400 Data file Version 4.0.0. doi:10.4232/1.12777. Retrieved from: https://dbk.gesis.org/dbksearch/sdesc2.asp?no=5400\&db=e\&doi=10.4232/1.12777 (accessed on 14 October 2018).

Jorrat, J. R. (2011). Clase, identidad de clase y percepción de las sociedades desde elitistas a igualitarias: un estudio comparativo internacional. CD ROM IIGG (2011) Movilidad y cambio social en América Latina. Buenos Aires: IIGG. ISBN, 978-950.

Ministerio de Trabajo, Empleo y Seguridad Social (2018). Resolución 3/2018 Fíjase salario mínimo, vital y móvil y prestaciones por desempleo, presentada en agosto de 2018 por el Consejo Nacional de Empleo, Productividad y Salario Mínimo Vital y Móvil. Retrieved from: http://servicios.infoleg.gob.ar/infolegInternet/anexos/310000314999/313259/norma.htm

Niehues, J. (2014). Subjective perceptions of inequality and redistributive preferences: An international comparison. Cologne Institute for Economic Research. IW-TRENDS Discussion Paper, (2).

Observatorio de la Deuda Social Argentina (2018). Incidencia de la indigencia y la pobreza por ingresos a partir de la encuesta de la deuda social argentina (2010-2018). Retrieved from: http://wadmin.uca.edu.ar/public/ckeditor/Observatorio\%20Deuda\%20Social/Presentaciones\%202018/2018/ 2018-Observatorio-Informe-POBREZA-MONETARIA-EDSA-ODSA-2010-2018.pdf

Page Group (2018). Estudio de Remuneraciones 2018. Retrieved from: https://www.apertura.com/economia/Salarios-cuanto-se-pagara-en-2018-segun-cada- posicion-201803050007.html

Rodríguez, S. A. (2014). Percepciones de desigualdad socioeconómica: Un estudio exploratorio para el caso argentino. Revista de Ciencias Sociales, 27(34), 93-118.

Schalembier, B. (2015). Measuring perceived income inequality: an evaluation of different methods. In Statistical Conference (SIS 2015).

van Stekelenburg, J., \& Klandermans, B. (2013). The social psychology of protest. Current Sociology, 61(5-6), 886-905.

Wegener, B. (1987). The illusion of distributive justice. European Sociological Review, 3, 1-13.

Wegener, B. (1990). Equity, relative deprivation, and the value consensus paradox. Social Justice Research, 4(1), 65-86.

Wegener, B. (1992). Concepts and measurement of prestige. Annual Review of Sociology, 18(1), $253-280$.

\section{Note}

The present research was developed within the framework of the research program "Poverty, inequality and social inclusion" at the Instituto de Psicología Básica y Aplicada (IIPBA) of the Universidad Católica de Cuyo (UCCuyo). The first author of this article is the beneficiary of a doctoral fellowship co-financed between the UCCuyo, the Consejo Nacional de Investigaciones Científicas y Técnicas (CONICET) and the Secretaría de Estado de Ciencia, Tecnología e Innovación (SECITI) of the Province of San Juan, Argentina. 